To cite this article: Schliephack, J. \& Dickinson, J.E., (2016). Tourists' representations of coastal managed realignment as a climate change adaptation strategy. Tourism Management, 59, 182-192. doi:10.1016/j.tourman.2016.08.004.

\title{
Tourists' representations of coastal managed realignment as a climate change adaptation strategy
}

\begin{abstract}
In coastal destinations climate change adaptation is needed to address coastal erosion due to a combination of sea level rise and more frequent extreme weather events leading to loss of natural features and tourism infrastructure. Managed realignment is increasingly adopted as a strategy to address coastal change; however, this has often proved a contentious strategy with stakeholder groups. This study explores tourists' representational framework of managed realignment and how this frames understanding of the concept, understanding of how coastal resources might change and implications for future visitation. Data compiled using a questionnaire adopted a social representations theory perspective to analyse how collective tourists' ideas may serve to mobilise the public in various ways. In general tourists have a poor understanding of managed realignment anchored to historic coastal management strategies and contextualised by use values with consequent implications for tourism planning and coastal management decision making.
\end{abstract}

Keywords: climate change; managed realignment; social representations; coastal erosion

\section{Introduction}

As a climate-sensitive sector, the tourism industry is facing impacts due to climate change which will affect the attractiveness of many destinations (Jopp et al., 2013; Wong et al., 2013). Sea level rise is likely to have profound impacts on coastlines around the globe (Gurran et al., 2013) in locations highly important for tourism (Ergin et al., 2006; Houston, 2008) and many coastal destinations face severe erosion leading to loss of sand, land and tourism infrastructure (Mycoo, 2014). For example, a third of the English and Welsh coastline is currently protected by defences aiming to protect people and property from flooding and erosion (Greene, 2006). In recent years, governments have started to question the goal of defending the coastline at all cost and policy is gradually shifting from maintaining hard defences towards working with nature (Early, 2008). Holding the line is a cost intensive measure (Early, 2008; Greene, 2006) which is not feasible for every location in the long term.

Many of the destinations projected to be most severely affected by climate change and sea level rise are in the least developed countries, developing countries and small island developing states (Hinkel et al., 2013; Mycoo, 2014), which have low adaptive capacity (Intergovernmental Panel on Climate Change, 2014), therefore an increasing number of destinations are unlikely to be able to maintain engineered protection. In developed regions, such as the EU, coastal destinations with limited hard or soft engineering measures are often small and rural destinations where communities depend on tourism as a source of economic activity. In the UK, tourism is a key industrial sector (McEvoy et al., 2008; Tourism Alliance, 2012) and seaside towns are a crucial part of this industry.

Managed realignment is a soft engineering approach to sustainably address coastal erosion through working with the natural process of coastal environmental change (Esteves, 2014). In many implementation contexts managed realignment has proved contentious with local residents since communities feel vulnerable to natural processes that impact on local assets (Myatt et al, 2003a; 2003b; Roca \& Villares, 2012; Ryan et al., 2012; Weisner \& Schernewski, 2013). There has been comparatively little work exploring the implications of 
sea level rise for tourism assets (Scott et al., 2012; Weaver, 2011) despite the likely physical impacts being widely recognised in the fields of environmental science, oceanography and coastal engineering. In particular there is a lack of research on tourists' understanding of the strategic approaches, perceptions of likely changes to the tourism resource and implications for visitation patterns (Jopp et al., 2010; Michailidou et al., 2016). This is a significant gap given that coastal areas are often economically reliant on tourism (Scott et al., 2012; Reddy, 2013) and the IPPC's $5^{\text {th }}$ Assessment Report identifies this as a priority research area (Scott et al., 2016). Destinations have low adaptive capacity in comparison to tourists. It is therefore vital to understand how perceptions of change and management strategies might influence tourist behaviour (Jopp et al., 2013).

Moscovici's (1981) social representations theory is used to frame the research. This theory, developed in social psychology, is particularly relevant where people encounter and make sense of a new concept such as managed realignment. The theory focuses on how various understandings of a new concept are socially and contextually derived and take on particular meanings to social groups. The theory has been applied to the study of risk in other contexts where it explores how risk evolves, why particular representations emerge, become accepted and are symbolic to some groups (Joffe, 2003). The paper aims to explore tourists' representational framework of managed realignment and how this frames understanding of the concept, understanding of vulnerability of coastal tourism attributes and behavioural implications of changes for future visits.

\section{Sea level rise, managed realignment and tourism}

Tourism research on adaptation to climate change in coastal areas is relatively thin (Becken, 2013; Jopp et al., 2013; Scott et al,. 2016) and research on climate change adaptation in general is less developed in tourism compared to other sectors (Matasci et al., 2014). Sea level rise and an increasing number of extreme weather events will cause a loss of low lying land along coastlines and will cause erosion of beaches and cliffs (Hadley, 2009; Hamilton, 2007; Hinkel et al., 2013). These physical impacts will also impact ecosystems and society by causing a loss of habitat and beach resources through 'coastal squeeze' (Ryan et al., 2012), a process where physical structures, such as seawalls or roads, prevent natural realignment processes (Scott et al., 2012). Sea level rise is a long-term and gradual process, however, extreme events are short term and can alter a shore in the matter of hours (Scott et al., 2012). Considering the high likelihood of sea level rise in the future, impacts of extreme events will be exacerbated leading to socio-economic consequences (Hinkel et al., 2013; Sano et al., 2015). Erosion is a wide spread issue as about $70 \%$ of sandy beaches are eroding worldwide (Bird, 1985).

The vulnerability of tourism in coastal areas will depend on the levels of exposure, sensitivity and the adaptive capacity of the destination (Lane et al., 2013; Michailidou et al., 2016). Exposure refers to the extent of anticipated physical changes due to climate change, such as sea level rise, while sensitivity reflects the location characteristics that lead to differentiated impacts (Sano et al., 2015). Destinations with better adaptive capacity will be more able to respond to changes and this depends on a range of factors including social and economic resources (Sano et al., 2015). There is a need for climate change to be integrated into coastal management policies (Sano et al., 2015). This includes tourism which is not only physically, but also economically and socially vulnerable. Coastal management strategies seek to protect vulnerable areas from risks that may not pose a danger for decades and relatively little is known about people's responses to these strategies (Ryan et al., 2012; Jopp et al., 2013) and the implications for tourism demand (Scott et al., 2016).

Matasci et al. (2014) explored barriers to climate change adaptation in the tourism sector and found social feasibility was a significant barrier. This refers to stakeholders' difficulties in 
perceiving changes and grasping impacts, and their lack of awareness of adaptation measures. Society will be most likely to protect high value land, important infrastructure and cultural assets where possible (Scott et al., 2012). There are five coastal management policy approaches regarding sea level rise: hold the line; managed realignment or managed retreat; no active intervention (do nothing); advance the line; and limited intervention (Greene, 2006). All management approaches have different environmental, social and economic implications and one area may apply a combination of these approaches according to the characteristics of the location (Mycoo, 2014; Scott et al., 2012). In recent years, government policy has shifted from continuing hard defences (hold the line) towards working with nature (Early, 2008). In many destinations where beaches suffer from erosion, soft engineering measures such as beach nourishment are applied to not only protect the coast but also to maintain a sandy beach for tourism purposes (Hamilton, 2007; Phillips \& Jones, 2006). Structural protection or hard engineering, such as rock walls or dikes, often interfere with development goals of resorts, affecting undisturbed sea views and easy access to beaches (Hamilton, 2007; Scott et al., 2012).

Managed realignment is a deliberate and planned strategy of realigning coastal defences though exact definitions vary. It can involve building new defences further inland, removing defences, or allowing existing defences to collapse to enable natural processes and can result in creation of new habitat (Esteves, 2014). Managed realignment can lead to coastal advance as well as retreat and a critical element is enabling more natural processes to operate (Esteves, 2014). It is crucial to understand and deal with pubic views for truly sustainable outcomes and low levels of awareness and understanding generate conflict (Mataschi et al., 2014; Roca \& Villares, 2012). Even where people are aware of managed realignment, the general public does not have well informed views, lacks understanding (Myatt et al., 2003a; 2003b; Roca \& Villares, 2012) and can view managed realignment as a cost saving measure rather than a practical solution (Myatt et al., 2003a). Here social feasibility (Matasci et al., 2014) is evident as a barrier. A previous term, 'managed retreat', which is now largely defunct, implies land is given up to the sea (Esteves, 2014). This potential for loss of land is contentious (Roca \& Villares, 2012; Weisner \& Schernewski, 2013) with local people's interests feeling marginalised in comparison to environmental concerns (Esteves, 2014; Myatt et al., 2003a). There are also practical implementation issues. For instance, Barbados has a setback strategy to regulate coastal development and allow natural beach zone expansion and contraction, but this can be compromised by the extent of existing tourism development and resistance of private owners (Mycoo, 2014).

Managed realignment can benefit tourism as the natural coastal environment is reestablished, providing space for tourism and creating habitat (Hadley, 2009). Coastal ecosystems such as salt marshes, wetlands, beaches and dunes serve as natural protection from storm surges (Abel et al., 2011) and according to Greene (2006, p.4), "managed realignment will be the only truly sustainable coastal management option for this century and beyond". Areas with high tourism assets in urban contexts are likely to adopt a hold the line approach to sea level rise and this strategy dominates in the Mediterranean region (Roca \& Villares, 2012) and Australia's Gold Coast (Sano et al., 2015), however, managed realignment is increasingly an option for rural areas where it may affect small scale tourism assets which are likely to be important for the region.

Environmental features are an important element of tourist decision making (Braun et al., 1999; Uyarra et al., 2005). Significant changes as a result of sea level rise can either increase or reduce resort attractiveness, property values and room rates (Cowell et al., 2006; Houston, 2002). The impacts of sea level rise on tourism have been assessed in a number of high profile locations, for example, the cities of Alexandria in Egypt and Venice in Italy (El-Raey et al., 1999; Scott et al., 2010), Florida in the USA (Stanton \& Ackerman, 2007) and California (King et al., 2011). Degradation and loss of beaches is a significant 
concern (Scott et al., 2012; Schleupner, 2008) and hard defences, where essential, need to be designed with care to maintain attractive settings (Mycoo, 2014; Ryan et al., 2012).

Existing studies show tourists' reactions to degraded beaches are varied. It is not just the actual state of beaches but also tourist expectations. Where tourists have been influenced by marketing images of pristine beaches, they can feel deceived if their expectations are not met (Buzinde, Manuel-Navarrete, Eunice Eunjung, \& Duarte, 2010; Buzinde, ManuelNavarrete, Kerstetter \& Redcliff, 2010). If tourists perceive climate change to affect their expected need satisfaction, a change in destination choice can be anticipated (Braun et al., 1999). This is particularly important for destinations with high numbers of day and short stay tourists who frequently visit as these tourists can develop a sense of place (Bærenholdt et al., 2004; Hall, 2005) which is negatively affected by changes. Where tourism underpins the economy, tourists' expectations and reactions will impact on the adaptive capacity.

Destination adaptation approaches are complex due to the large number of stakeholders involved (Moreno \& Becken, 2009) and external factors including economic, social, environmental, political and technological aspects (Evans et al., 2003). Destinations need to build their resilience to climatic conditions to limit damage (Jopp et al., 2010). Several adaptation frameworks have emerged related to the vulnerability of coastal tourism destinations (see for example, Moreno \& Becken, 2009; Scott et al., 2006; Simpson et al., 2008; Becken \& Hay, 2007); however, little attention has been paid to the demand side in these analyses aside from a study by Jopp et al. (2010). One of the few studies to explore the impact of climate change on tourist behaviour (Coombes \& Jones, 2010) found weaker tourist preferences for facilities compared to beach characteristics and habitats suggesting changes in facilities would have limited impact on tourist numbers. Michailidou et al. (2016) suggest more work is needed to involve local stakeholders and Scott et al. (2016, p. 25) point out that the lack of knowledge on "tourist responses to climate change impacts and climate change policy interventions remain substantive barriers to tourism sector mitigation and adaptation responses at the destination level".

\section{Social representations theory}

Social representations enable people to orientate themselves in the world and communicate, particularly in relation to unfamiliar concepts. The theory lies between individual agency and social structure and focuses on an object of interest, the subject that undertakes the representation (individual agency) and the social group the subject is positioned in (social structure) (Voelklein \& Howarth, 2005). There can exist a plurality of representations (Joffe, 2003) and individuals can sometimes choose to use different representations deploying a social representation that seems most appropriate to a given social context (Moscovici \& Hewstone, 1983; Voelklein \& Howarth, 2005). People seek to fit norms of a group and there can be rules about which representation is acceptable (Moscovici \& Hewstone, 1983). In this way a representation can be perpetuated even if someone does not entirely support the view. To this end the theory differs from perception studies (Joffe, 2003), it is not deterministic and requires a descriptive and inductive approach with diverse methods used (de Rosa, 1994). The theory invites research to not just describe representations but also to analyse the social function of representations (Voelklein \& Howarth, 2005). Thus a focus of social representations studies is how individuals' share the same symbolic codes, in what context social representations are produced and communicated, and how they function (de Rosa, 1994).

Social representations theory is relevant to managed realignment which is a highly emotive topic related to climate change risk. Social representations bring meaning to abstract ideas, especially ones with some ambiguity like managed realignment. For instance, the scientific explanation of managed realignment has evolved overtime, however, even in scientific 
circles it can be represented as a coastal retreat strategy despite potential for land gain in some contexts (Hadley, 2009). Social representations theory is particularly useful to understand how scientific knowledge is transformed into lay thinking. It looks at how an idea evolves, why that idea was created and accepted (Moscovici \& Hewstone, 1983). Often the general public first come to understand a new concept through the media which can simplify and sensationalize issues (Joffe, 2003). For example, Matasci et al. (2014) found stakeholders' scientific knowledge of climate change adaptation in the Swiss mountains was primarily derived from second hand sources such as newspapers, television and radio.

There are also issues of trust (Matasci et al., 2014). For example, in a German study of managed realignment, public views became polarised due to unexpected outcomes, highlighting the problems of communicating uncertainties, and this activated opposition (Weisner \& Schernewski, 2013). From a social representations perspective the facts (unexpected outcomes) did not correspond with communications from the scientific project team which enabled lay people with little technical knowledge to build a negative social representation and local people rejected the proposed managed realignment strategy.

Social representations are flexible and people draw on them to make interpretations and inferences that they compare to other knowledge (Moscovici \& Hewstone, 1983). Scientific knowledge is transformed into lay thinking through two processes, anchoring and objectification. People bring what they already know to the fore. For example, managed realignment maybe aligned with images of coastal erosion. This is known as 'anchoring' as a concept is aligned to existing ideas (Joffe, 2003). The anchoring process can misrepresent the scientific concept, for example, managed realignment could be anchored solely to strategies of building or repositioning hard sea defences which is the historical practice in many destinations. This represents a limited view. 'Objectification' works in tandem with the anchoring process and transforms the anchored concepts to current experiences of the world (Joffe, 2003). This works in such a way to defend individuals against threat to their identity, therefore people will draw on emerging representations that are acceptable to their group and context (Joffe, 2003). Facts "that do not correspond to the representations are seen as less real than those that do" (Moscovici \& Hewstone, 1983, p119). For instance, if an individual shares a group context where coastal processes are seen as a threat, managed realignment might be objectified as a negative strategy since it implies less hard coastal defences. It is therefore important to explore the context of the representation and external sources that generate representations. It is not particularly useful to consider whether representations are correct relative to scientific knowledge, rather the interest lies in how and why they are created. "They are the 'reality' in the minds of those who look upon the risks" (Joffe, 2003, p68).

\section{Methodology}

\subsection{Case study}

In order to explore tourist representations of managed realignment, Studland, a beach destination on the south coast of England was chosen. The beaches are managed by the National Trust, a UK conservation organization, who own large areas of the UK coastline. The beaches attract over 1 million tourists annually (National Trust, 2008) making them an important attraction for the area. The site is at 'high risk' from climate change. The southern end of Studland's beach is experiencing erosion and all tourist facilities including car parks, Information Centre, toilets, retail and catering facilities, and 258 beach huts located at various sites are at threat of storm events and future coastal erosion (National Trust, 2008). The cost of relocating Studland's tourist facilities to safer grounds is estimated to be £3.6 million (National Trust, 2008) and temporary facilities that can be relocated are currently 
being considered. There is provision of overflow car parking further from the beach (Living with a Changing Coast Project, 2014).

Despite erosion, the beaches are largely unprotected by hard engineering measures. Gabion baskets are in place at two beach locations, protecting tourist facilities and beach huts; however, these cause erosion further north. The National Trust has implemented a managed realignment scheme at Studland in accordance with the region's Shoreline Management Plan (Guthrie \& Ridgewell, 2011). The existing defence measures will not be renewed once they reach the end of their life to enable natural shoreline dynamics and to maintain the beach's natural scenery. This will lead to natural coastline erosion that will maintain the beach (Living with a Changing Coast Project, 2014). Despite the importance of tourism to the region (South West Research Company, 2014), the National Trust are keen to reduce tourist numbers at peak time due to pressure on the natural environment which has international conservation importance. Therefore managers have been willing to implement a strategy that has potential implications for visitation. Studland provides a good example of a popular beach destination which also faces changes due to sea level rise and an increased number of extreme weather events (McDonald, 2012; Living with a Changing Coast Project, 2014). A high degree of change is anticipated for both natural features and tourist facilities.

\subsection{Study design}

In society different groups will draw on or emphasise different dimensions of social representations and an approach was needed to capture this information. A questionnaire was developed and reflects wide use of questionnaires in social representations theory studies (see for example, Fredline \& Faulkner, 2000). The analysis strategy was founded on inductive reasoning and employed cluster analysis and exploratory factor analysis to better understand respondents' representational frame. Representations of managed realignment were captured by an open question to avoid presenting attitudes to respondents: 'what do you understand by the term managed realignment and how it might affect the coast at Studland?' An open question of this nature presents complexity for respondents; therefore the questionnaire included the option 'I do not understand managed realignment at all' to reduce effort for respondents (Bryman, 2001). Piloting demonstrated that a proportion could provide a meaningful answer so the open questioning strategy proceeded. Open questions have advantages for a social representations study as respondents can answer in their own terms, they allow unusual responses and the question does not prompt respondents so it is possible to explore saliency of the topic (Bryman, 2001).

The open question answers were content analysed and reduced to key categories (Weber, 1990). An emergent coding system was developed based on recording units of words or brief phrases. Two researchers reviewed the answers and developed a category list.

Stemler's (2001) procedure was followed where notes were compared and the category list amended. The resultant coding checklist was applied to the data independently by the two researchers. The coding was compared, any disagreement discussed and amended. 18 categories were proposed, however, given the study's interest in shared representations, categories used by less than $10 \%$ of the sample were dropped. Though this is an arbitrary cut off point, it has been applied in other areas where social representations studies are interested in the level of agreement among relatively large clusters (Hammond, 1993; FifeSchaw, 1993). The remaining seven categories were entered into SPSS as binary data (presence/absence) for each category.

A hierarchical cluster analysis was used to explore the representational field. This is an exploratory technique that searches for agreement among respondents and organises them into groups on the basis of this agreement (Fife-Schaw, 1993). Cluster analysis will produce clusters regardless of whether there is actual structure (Hair et al., 2010) and there is no use 
of statistical inference to identify the best solution (Fife-Schaw, 1993). It is ultimately the subjective judgement of the researcher, therefore cluster results were examined carefully to explore their sense based on the social representations perspective and several exploratory cluster analysis approaches were deployed. The final analysis used an average linkage within groups method, which produces tight clusters, and a pattern difference measure which is a dissimilarity measure for binary data. The choice of similarity measure is significant as when two respondents negate to cite a particular attribute this joint absence does not necessarily imply agreement as a respondent might have simply not noted that attribute in an open question (Hammond, 1993). For instance, while the study is interested in whether respondents include 'natural processes' or 'human intervention', the absence of 'human intervention' does not mean the respondent does not consider this an element of managed retreat. Thus a pattern difference measure is appropriate here rather than simple matching which compares equally both presence and absence.

An examination of the agglomeration schedule (a numerical summary of the cluster solution which indicates how clusters are combined) suggested there were no outliers. The cluster analysis initially yielded a solution with one cluster focused on a category coded 'beach'. As this was a rather generic term given the context of the study, the 'beach' category was excluded in further analysis. The final cluster solution was determined on the basis of the agglomeration schedule, the dendrogram (a diagram that visually represents the clusters) and the subjective sense of the clusters. The final cluster groups were examined against classifying variables such as demographics and visitation patterns using cross-tabulation and chi-square test.

While use of scales is contentious in social representations studies as they prompt an attitude towards the object (Doise et al., 1993), they were used to explore which destination features affect respondents' enjoyment of Studland's beaches. This was appropriate since beach visitation is established in the British psyche and respondents are not forming representations of a new concept. A list of natural and amenity features was created in conjunction with site managers. Factor analysis was used as an exploratory technique to explore the structural relationships between the variables and hence the underlying structure to tourist enjoyment (see for example, Castro \& Lima, 2001). The resultant factors identify salient attributes and summarize the representational field for the sample (Doise et al., 1993). A key limitation is the constraint a list of items places on respondents' ability to describe salient attributes (Pukhardt \& Stockdale, 1993). As factor analysis was used descriptively the assumptions of normality are not in force (Tabachnick \& Fidell, 1989).

Principal axis factoring was employed. This is a descriptive method (Hammond, 2000) that is used in exploratory studies when the results are not generalised beyond the sample (Field, 2013). The goal is to account for the maximum amount of variance within the data with much fewer new variables known as factors (Tabachnick \& Fidell, 1989). In social representations studies the technique is useful to explore the underlying structure of many variables as it identifies variables that are correlated with one another but largely independent of other subsets of variables (Tabachnick \& Fidell, 1989). On the assumption that the tourist enjoyment factors could be related to one another and exhibit some correlation an oblique rotation was initially applied (the DIRECT OBLIMIN option in SPSS) (Giles, 2002; Hammond, 2000). This is used in psychology research where it is anticipated that there may be some degree of correlation between the final factors (Giles, 2002). However, as the factor correlation matrix identified no correlations of 0.30 and above it was assumed the factors were independent and an orthogonal rotation was applied (the VARIMAX option in SPSS). An orthogonal rotation places the factors at right angles (Giles, 2002) to maximise loadings on each factor (Field, 2013).

Given the sample size, the scree plot was examined to identify the number of factors (Field, 2013). This was also examined from an interpretability perspective (Hammond, 2000). 
During the process two input variables were excluded from the analysis. The first, 'quality of the water', exhibited limited correlation with other variables and had low factor loadings. The second, 'accessibility of Studland', had a relatively low loading on one factor alone and was removed from the analysis. In retrospect this was recognised to be a vague concept that could be interpreted in different ways. The robustness of the final solution was examined. There were no particularly low values in the communalities table. Sampling adequacy was measured using the Kaiser-Meyer-Olkin Measure. This varies between 0 and 1 with values of .6 or above needed for a good factor analysis (Tabachnick \& Field, 1989). The value of 0.706 was adequate. Bartlett's Test of Sphericity was used to identify if correlations between variables are too small. The result was significant at $p<.001 \quad(p<.05$ is typically the threshold) indicating there are some relationships between the variables and factor analysis is appropriate. The resultant factors scores were examined against classifying variables such as demographics, visiting characteristics and the managed realignment clusters using t-tests and ANOVA as appropriate.

Tourist understanding of features that might change due to climate change and sea level rise was captured using an attribute checklist based on the site managers' anticipated changes. This included both likely changes and less likely scenarios given the uncertainties with climate change. The same list of attributes was used to understand which changes would reduce return visits. The binary data on anticipated changes (present/absent) was subject to a hierarchical cluster analysis to explore agreement using a within group linkages method. Where there is little agreement in large clusters there is little evidence that there is a consensual representation (Fife-Schaw,1993). Simple matching for binary data was appropriate here since it measures both presence and absence of an attribute and respondents had to actively decide to tick or not tick each attribute. The 'no change' attribute was not included. No outliers were identified. Cluster groups were compared against demographic and visitation patterns using cross-tabulation and chi-square test.

The questionnaire was self-completed and administered at Studland beach. Questionnaire completion took less than 10 minutes which is considered a maximum for site based surveys (Davidson, 1970). Since a sampling frame is not available for open access tourism sites a systematic sampling approach was applied to select respondents on site. A random starting point on one of the beaches was allocated each day and the five closest tourists or tourist groups were approached and the questionnaire handed out. After completion, the questionnaires were collected and the researcher moved about $30 \mathrm{~m}$ along the beach where the next five closest tourists were approached.

The survey was conducted over eight days in two phases. The first phase surveyed tourists between the 7th and 13th of July 2014, a period outside of the school holidays, and the second phase surveyed tourists between the 21st and 27th of July 2014, during school holidays. This captured a diversity of tourists, albeit during the summer season. Survey days included weekdays as well as weekend days and tourists were surveyed at different times ranging from $10 \mathrm{am}$ to $5.30 \mathrm{pm}$. A total of 348 responses were collected. 13 people refused to take part which equals a response rate of $96 \%$. The high response rate (Finn et al., 2000) is related to the personal approach by the researcher, relative brevity of the questionnaire and because respondents were generally seated at a relaxed location with time available. Out of the 348 responses, 343 were useful for analysis.

\section{Results and discussion}

\subsection{Social representation of managed realignment}

When exploring social representations the interest generally lies in shared attributes, though this can exclude more unique perspectives that might ultimately contribute to new 
representations. $55 \%$ of respondents provided an explanation of managed realignment in response to the open question, with seven categories used by $10 \%$ or more of the sample (Table 1). 'Human intervention' emerged as the dominant idea and suggests managed realignment was anchored to the historic approach of 'holding the line' adopted in the UK. 'Natural processes' was also an important content category and this was used both in conjunction with human intervention, for example, 'managing natural processes', or independently, for example, 'natural processes will take place anyway'. Other categories identify 'erosion' taking place, the need to 'protect' features, various forms of 'amenity benefits' related to facilities or tourist enjoyment and various references to 'wildlife and ecosystems'. Respondents also frequently referenced the 'beach' which reflects the survey context. 
Table 1. Main managed realignment explanation categories

\begin{tabular}{|c|c|c|c|}
\hline Category & Explanation & Examples & $\%$ \\
\hline $\begin{array}{l}\text { Human } \\
\text { intervention }\end{array}$ & $\begin{array}{l}\text { Mention of } \\
\text { management or } \\
\text { human intervention }\end{array}$ & $\begin{array}{l}\text {-artificially/controlled migration of sand along } \\
\text { beach } \\
\text {-changing the way the coast is eroded and } \\
\text { flooded by building defences/barriers }\end{array}$ & 66 \\
\hline $\begin{array}{l}\text { Natural } \\
\text { processes }\end{array}$ & $\begin{array}{l}\text { Mention of natural } \\
\text { processes }\end{array}$ & $\begin{array}{l}\text {-allowing nature to erode } \\
\text {-letting nature take its course } \\
\text {-allowing nature to erode/deposit with little or } \\
\text { no interference. } \\
\text {-the sea is allowed to do as it will }\end{array}$ & 43 \\
\hline Erosion & $\begin{array}{l}\text { Use of the term } \\
\text { erosion }\end{array}$ & $\begin{array}{l}\text {-changing the way the coast is eroded. } \\
\text {-managing erosion. }\end{array}$ & 33 \\
\hline Beach & $\begin{array}{l}\text { Reference to } \\
\text { beach or beaches }\end{array}$ & $\begin{array}{l}\text {-profile of beach } \\
\text {-composition of beaches }\end{array}$ & 31 \\
\hline $\begin{array}{l}\text { Amenity } \\
\text { benefits }\end{array}$ & $\begin{array}{l}\text { Reference to 'use } \\
\text { values', for } \\
\text { example, beach } \\
\text { huts, car parks, } \\
\text { tourism, recreation, } \\
\text { facilities, natural } \\
\text { beauty }\end{array}$ & $\begin{array}{l}\text {-beauty of the area } \\
\text {-maintained for hut users, café and walkers } \\
\text {-public not allowed to use } \\
\text {-improve facilities } \\
\text {-controlling areas of visitation and car parking } \\
\text {-to preserve it as a tourist spot }\end{array}$ & 24 \\
\hline Protection & $\begin{array}{l}\text { Use of word } \\
\text { protect, protection } \\
\text { or similar, for } \\
\text { example, preserve }\end{array}$ & $\begin{array}{l}\text {-measures used to protect... } \\
\text {-managing the natural environment of the } \\
\text { coastline to protect... }\end{array}$ & 13 \\
\hline $\begin{array}{l}\text { Wildlife and } \\
\text { ecosystems }\end{array}$ & $\begin{array}{l}\text { Use of wildlife and } \\
\text { ecosystem terms, } \\
\text { named habitats or } \\
\text { species }\end{array}$ & $\begin{array}{l}\text {-natural physics geography of the area - } \\
\text { wildlife/habitats } \\
\text {-to preserve habitat and biodiversity is } \\
\text { acceptable unless detrimental to coastal } \\
\text { ecosystems }\end{array}$ & 12 \\
\hline
\end{tabular}

The cluster analysis using these categories yielded a three cluster solution as follows:

Cluster $1(\mathrm{n}=74)$ associated with natural processes.

Cluster $2(n=57)$ associated with human intervention and erosion.

Cluster $3(n=47)$ associated with human intervention and amenity.

The associations made by each group all broadly fall within the remit of managed realignment, but each cluster is aligned with a distinctive representation. The largest cluster appears anchored to respondents' recent experience of extreme weather in the UK where natural processes caused significant damage to coastal areas and infrastructure in winter 2013-2014 (Met Office, 2014). This was extensively reported in the media. Clusters 2 and 3 are both associated with the dominant idea of human intervention. There was a small gender effect $\left(X^{2}=6.271, d f=2, p=.043\right)$ with men associated with cluster 1 in which natural processes dominated. 
The quantitative strategy described above is necessarily reductive and strips away much of the nuances of answers. Most respondents struggled to articulate clearly the meaning of managed realignment with many prefacing answers with 'I think' or 'I'm guessing' suggesting limited knowledge. Individual interpretations of managed realignment were often very confused and indicate that lack of awareness of adaptation measures is likely to be a social feasibility barrier to adoption (Matasci et al., 2014). The quantification also obscures some of the more revealing answers which show how individuals might politically deploy a social representation. For example, several respondents focused on costs, for example:

"You've given up protecting it which is good as my council tax will be less"

"Another term for maximising profit without spending"

These respondents aligned their representation to governmental or managing organisation cost saving strategies. This reflects negative opposition to managed realignment schemes experienced elsewhere (Esteves, 2014) where commonly held beliefs can be a barrier to implementation of effective coastal management (Ryan et al., 2012). In developed countries state intervention is well established as a mechanism to protect vulnerable assets at risk. Therefore people tend to believe the state will intervene to protect assets and managed realignment can be seen as a cost cutting strategy. Such a representation would function to challenge political decisions.

\subsection{Valued features of the destination}

Most features contribute to tourist enjoyment (Table 2); however, the natural setting and beach access from car parks are most valued. The importance of the natural setting aligns with the managed realignment strategy to maintain the natural character of the site and to reinstall natural coastal processes (Living with a Changing Coast Project, 2014). 
Table 2. Features affecting tourist enjoyment of Studland's beaches

\begin{tabular}{lrrrr}
\hline & Mean & Std. Deviation & S & K \\
\hline $\begin{array}{l}\text { Statements with strong } \\
\text { agreement }\end{array}$ & & & \\
The natural setting & 4.71 & .663 & -2.996 & 10.749 \\
Beach access from car parks & 4.57 & .818 & -2.386 & 6.176 \\
& & & & \\
Statements with agreement & & & & \\
Quality of water & 4.47 & .822 & -1.806 & 3.698 \\
Proximate parking facilities & 4.42 & .913 & -1.846 & 3.324 \\
Proximity of toilets & 4.35 & .895 & -1.573 & 2.526 \\
Sandy beach at Knoll beach & 4.33 & .922 & -1.396 & 1.726 \\
Accessibility of Studland & 4.19 & .986 & -1.066 & .514 \\
Ability to walk along the beach & 4.18 & .955 & -.907 & .116 \\
Proximity of café facilities & 4.15 & .929 & -1.096 & 1.047 \\
Sandy beach at Middle Beach & 4.14 & .908 & -.922 & .699 \\
Sandy beach at South Beach & 4.02 & .928 & -.554 & -.339 \\
Possibility of observing wildlife & 3.86 & .952 & -.534 & .035 \\
Interpretation and information & 3.58 & .890 & -.124 & .122 \\
& & & & \\
Statements with neutral & & & & \\
responses & & 1.106 & -.105 & -.396 \\
Water sports & & & .145 & -.265 \\
Availability of beach huts & 2.18 & & & \\
\hline
\end{tabular}

The factor analysis yielded a four factor solution which accounted for $64 \%$ of the total variance which is adequate (Doise et al., 1993). This suggests a representational field that organises beach enjoyment into four salient aspects (Table 3):

Factor 1 (27\% of variability) has high loadings on items related to tourist facilities (parking, café, toilets). Labelled: general facilities.

Factor 2 (14\% of variability) has high loadings on items related to natural setting, wildlife and observing this. Labelled: natural setting.

Factor 3 (12\% of variability) has high loadings on items related to sandy beaches. Labelled: sandy beaches.

Factor 4 (10\% of variability) has high loadings on two items related to water sports and beach huts. Labelled: niche facilities. 
Table 3. Principal axis factor analysis of tourist enjoyment statements

\begin{tabular}{|c|c|c|c|c|}
\hline & \multicolumn{4}{|c|}{ Factor } \\
\hline & $\begin{array}{c}1 \\
\text { General } \\
\text { facilities }\end{array}$ & $\begin{array}{c}2 \\
\text { Natural } \\
\text { setting }\end{array}$ & $\begin{array}{c}3 \\
\text { Sandy } \\
\text { beaches }\end{array}$ & $\begin{array}{c}4 \\
\text { Niche } \\
\text { facilities }\end{array}$ \\
\hline Proximate parking facilities & .874 & & & \\
\hline Beach access from car parks & .822 & & & \\
\hline Proximity of toilets & .664 & & & \\
\hline Proximity of cafe facilities & .494 & & & \\
\hline Possibility of observing wildlife & & .890 & & \\
\hline Ability to walk along the beach & & .507 & & \\
\hline Interpretation and information & & .479 & & \\
\hline The natural setting & & .459 & & \\
\hline Sandy beach at Middle beach & & & .841 & \\
\hline Sandy beach at South beach & & & .638 & \\
\hline Sandy beach at Knoll beach & & & .470 & \\
\hline Water sport offers & & & & .647 \\
\hline Availability of beach huts & & & & .578 \\
\hline
\end{tabular}

These findings are specific to Studland and indicate distinct areas that managers need to consider in a managed realignment scheme. Respondents discriminate between general facilities and those such as beach huts and water sports that are niche facilities, the later having less explanatory power. At Studland both sets of facilities are likely to be affected by managed realignment, however, while the natural setting will alter to some extent it would not substantively change the elements tourists enjoy. For example, the presence of sandy beaches is not anticipated to change. Additional analysis explored the variability of this representational field in respect to demographics and visitation patterns.

Gender differences were apparent with respect to factor $1(t=-2.070, p=.04$, men mean -.156 , std dev .962, women mean.097, std dev .894). General facilities are more salient for women and relate to family visitation patterns where such facilities are desirable for children. This to some extent contradicts the findings of Coombes and Jones (2010) who found beach characteristics were more important and indicates facilities are significant for some tourists. To further illustrate this, niche facilities were more salient for local residents who make use of beach huts. The relocation of beach huts may not be avoided, however, the NT is working on developing a new design for beach huts at Studland that can withstand some of the near term consequences of sea level rise, such as increased flooding (Living with a Changing Coast Project, 2014). Relocation of some of the beach huts will be part of the adaptation process, reducing vulnerability and hence leading to an increased resilience to impacts. These demographic and visitation patterns indicate that respondents draw on the enjoyment aspects that reflect their context of use. There was no relationship between the managed realignment explanation cluster groups and the factor scores.

\subsection{Destination features anticipated to change due to climate change and impact on future tourism}

Tourists anticipate changes to Studland's beaches due to climate change and sea level rise and analysis indicates that less sand and reduced access are aspects of concern. Figure 1, which compares anticipated change with impact on visitation, shows these features are in the upper right quadrant where over $30 \%$ of tourists expect change and over $30 \%$ indicate this would lead to reduced visitation. However, less sand is not anticipated by managers and 
given that Studland suffers from intense tourism pressure to sensitive ecosystems, in this instance, the impact of reduced access would be of less concern to the destination managers and reflects their plans to allow loss of beach side car park spaces. On the other hand, reduced access is significant for some local businesses, especially as almost $90 \%$ of tourists come by car and value the proximity of car parks. There are also other access issues. For instance, loss of the coastal path, which has been diverted inland, makes part of the beach less accessible and diverts passing trade away from a beach café. Managers need to be mindful that climate change can not only alter environmental features of destinations (Rowell \& Richins, 2013) but also access which can also affect attractiveness (Leiper, 2004).

The intention to return should be treated with caution as behavioural intentions are notoriously difficult to predict, especially in instances such as this where tourists do not fully understand how the destination might alter. In general, participants' willingness to return is quite high for most changes and relates to the diversity of tourism activities at Studland. Loss of sand/beaches is of most concern and reflects work by Uyarra et al. (2005) in the Caribbean who found that up to $80 \%$ of tourists' decisions to return would be affected if beaches were degraded by climate change. The managed realignment strategy at Studland involves not renewing gabion baskets that are installed in several places along the beach and will allow for a natural recharge of sand (Living with a Changing Coast Project, 2014). Thus, there will always be some sandy beaches in Studland, however, loss of sand/beaches is a concern elsewhere (Mycoo, 2014). The UK south coast includes small seaside destinations protected by sea walls. In these contexts erosion is likely to cause the loss of sandy beaches due to coastal squeeze if not replenished via costly beach nourishment. Given the attraction of sandy beaches these findings imply a potential large loss of tourists to these destinations. 


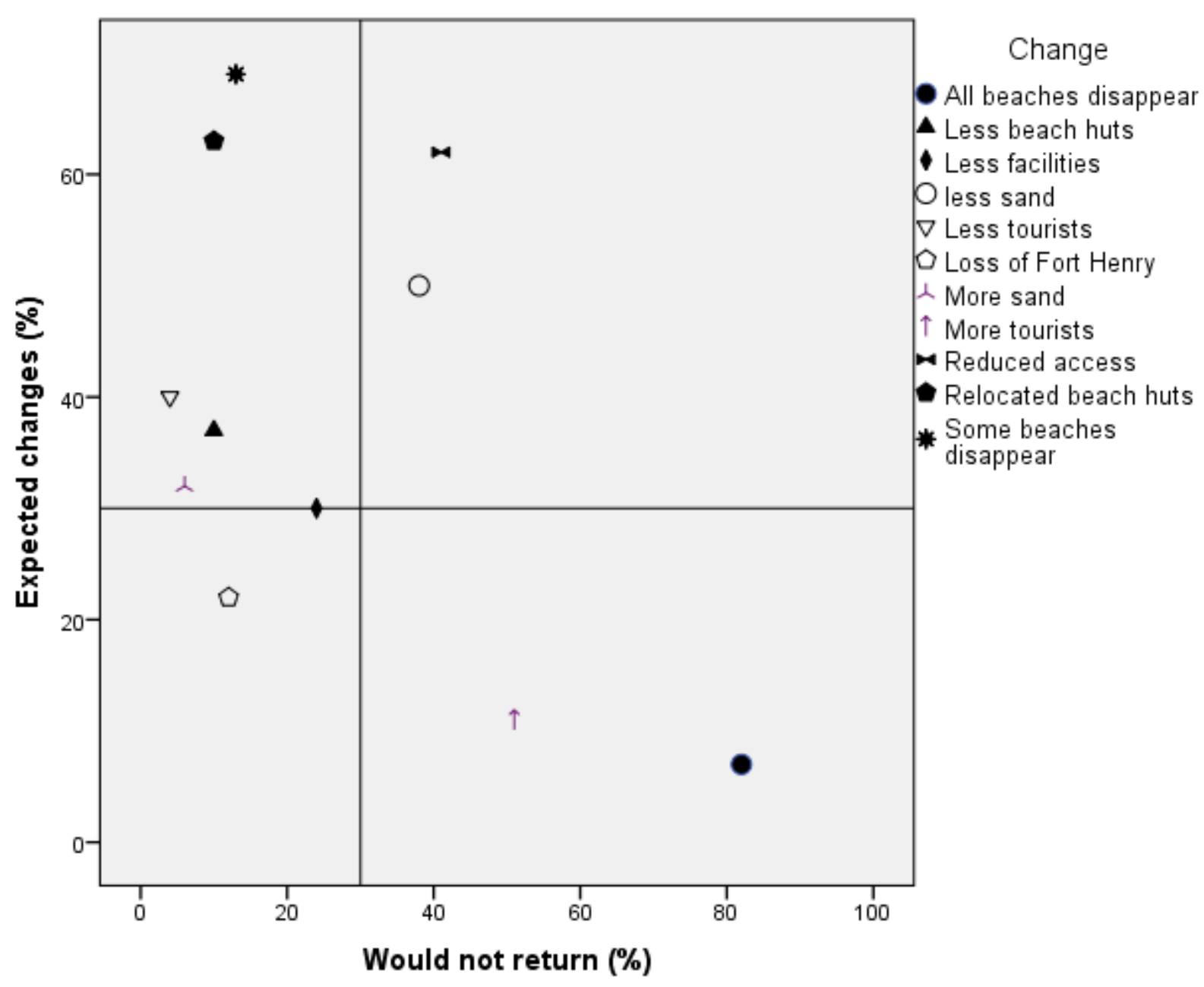

Figure 1. Expected changes and intention to return

The cluster analysis of expected changes identified three groups who represent changes in different ways:

Cluster 1 ( $n=169)$ assumes a business as usual scenario in which there is little change to the destination and tourism continues to flourish.

Cluster $2(n=85)$ expects many changes and has a representation that amenity values of the site will be affected.

Cluster $3(n=88)$ has a representation that beaches, the destination's dominant attraction, will be affected along with reduced access.

The implications of these three representations are illustrated in Figure 2. Understanding of managed realignment lies in the background denoted by the shaded circle with each segment proportional to the clusters identified in section 5.1. As discussed, knowledge of managed realignment was limited and often confused, with $45 \%$ of respondents expressing no understanding. The tourists' expectations of change are layered on top of this according to the three clusters identified.

The largest group acknowledges few changes (cluster 1, 49\%). This needs to be interpreted with care. On the one hand this reflects an understanding of coastal processes. Studland beach is relatively natural and coastal erosion will maintain this natural state, although tourist 
infrastructure will be affected. Managed realignment is planned to work with the natural processes and will be viewed positively by those who understand the strategy. The literature, on the other hand, suggests an alternative interpretation. Ryan et al. (2012) found there was unwillingness by some to consider the risk from climate change in Australian coastal communities and Matasci et al. (2014) found some tourism stakeholders fail to perceive changes and impacts of climate change in the Swiss mountains. Assuming this interpretation, Ryan et al. (2012) suggest this perspective would make it difficult for cluster 1 to engage with discussion about coastal management. Cluster 1's representation will not detract tourists, but it may reflect a strategy by some people to distance themselves from the problem and is evidence of climate change denial (Stoll-Kleemann et al., 2001). Given that changes resulting from climate change maybe some way in the future it could function to reject the legitimacy of current management actions. Such a representation will also be challenged if actual changes become apparent and contrast with tourist expectations leading to reduced satisfaction (see for example, Buzinde, Manuel-Navarrete, Kerstetter, \& Redcliff, 2010).

Cluster $3(26 \%)$ focused their representation on loss of sand and beaches. While this is unlikely to happen, this social representation has the power to bring about behaviour change regardless of the change physically taking place as these tourists represent the site's key feature as degrading. Managed realignment will maintain the beaches and is therefore likely to be supported; however, the analysis suggests this is not well understood. Given the traditional strategy of working with hard defences to protect features, this representation has the potential to mobilise opposition to managed realignment. Cluster $2(25 \%)$ focused their representation on many changes to facilities and access which will be altered at Studland. This could lead to tourist adaptation as they select other destinations and mobilise actions to oppose managed realignment if this is perceived to fail to protect key amenity features.

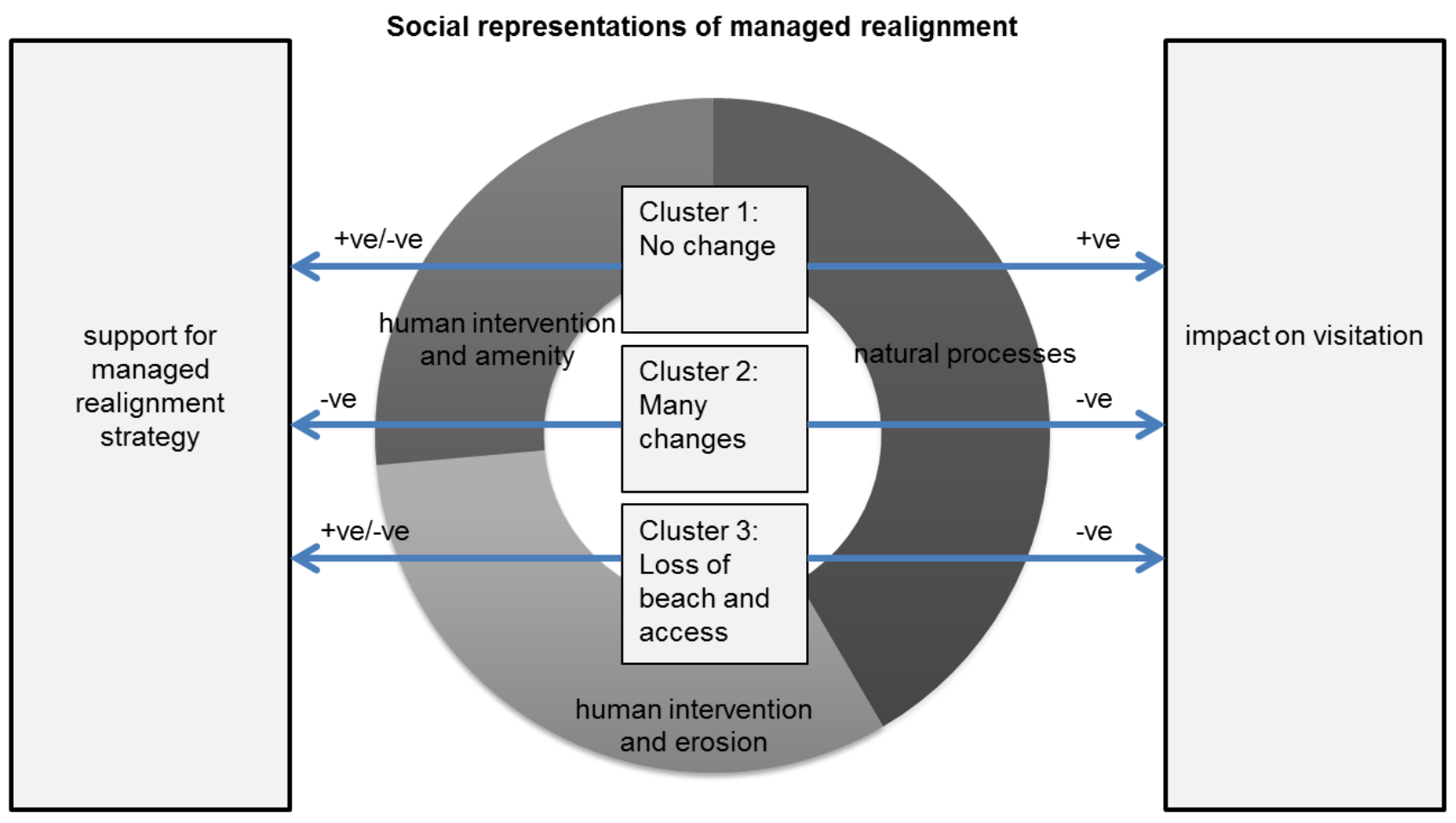

Figure 2. Implications of expected changes due to climate change 
No cluster membership patterns were found in relation to socio-economic characteristics or visitation patterns. There was also no association with these clusters and those identified on the basis of managed realignment explanations. This lack of association indicates a diverse representational field currently maps tourists' understanding of the managed realignment concept and anticipated changes. The representations are emergent, they do not align well with scientific understanding and there is much uncertainty.

\section{Conclusions and implications}

While social representations theory has previously been used in the analysis of risk (Joffe, 2003) this article has extended the scope to tourism adaptation to climate change. It provides a theoretical perspective that explores how the socio-cultural context shapes wider understandings of climate change adaptation. Social representations theory extends the knowledge of perception of adaptation strategies since it focuses not just on what the perception is, but seeks to analyse how it might have been derived, the purpose of the representation and the impact on behaviour. This study therefore makes a theoretical contribution to tourism adaptation to climate change by exploring the multiple social realities of managed realignment that circulate through society and how they might function. Managed realignment is a scientific concept and the way the idea is interpreted by tourists and perpetuated has significant implications for many tourism destinations. Given that social representations have considerable inertia (Fredline \& Faulkner, 2000) a representation of managed realignment has potential to exert a pervasive influence on tourist behaviour that will be difficult to alter.

In general tourists at Studland have a poor understanding of managed realignment that incorporates elements of the scientific definition, albeit in an inconsistent way. Furthermore, $45 \%$ expressed no understanding at all. The social representations are allied to respondents' recent experiences of coastal erosion in the UK and a hold the line approach which is the historic strategy adopted. This representation seeks to maintain the status quo where tourism amenity values appear protected. Social representations of changes to the destination that might arise due to climate change indicate potential evidence of climate change denial, as well as concerns about compromising amenity value. The findings reinforce previous work on tourism climate change adaptation that identifies social feasibility as a significant barrier (Matasci et al., 2014). Here two social feasibility barriers are evident: the difficulty in perceiving changes; and poor understanding of adaptation measures. More work is needed to address how ideas about climate change, its impacts and appropriate adaptation strategies circulate in society.

Given the uncertainty around climate change and that future changes may be far in the future, it is difficult to evaluate tourist behaviour responses. Intention to return was high for most changes, but there were important exceptions related to changes to beaches and access. Previous research on coastal management and climate change has focused on local stakeholders but paid less attention to tourists. However, tourists are central to destination economies. Tourists have high adaptation capacity in comparison to destinations (Scott et al., 2016) and tourists will seek other destinations should a social representation suggest less tourism amenity value, regardless of the physical reality.

The amenity value was explored in more detail and four dimensions derived: general facilities, natural setting, sandy beaches and niche facilities. General facilities, including parking, toilets and cafés, were most salient, likely to be impacted by managed realignment and important for particular segments of tourists, somewhat contradicting a previous study (Coombes \& Jones, 2010). This indicates a need for further research. While amenity values will vary from destination to destination and not all are compromised at Studland, managers 
need to be mindful that coastal management strategies have the potential to differentially impact on tourists seeking different experiences. There are several messages for destination managers. First, while actual physical changes to a destination can alter its attractiveness to tourists (Cowell et al., 2006), it is vital to recognise that social representations of changes, even when not physically realised, have a similar power to mobilise the public in various ways (Joffe, 2003). Similarly, the social representation of managed realignment does not have to be grounded in scientific reality to affect tourist behaviour and may serve to activate opposition. This is especially the case among local people where concerns lie with changes that would reduce tourism and be detrimental to the local economy. Social representations have much inertia and even when evidence contradicts a representation people will hold on to their views if it makes sense from their perspective. Second, a representation can provide a false sense of security. For instance, in this study nearly half of all respondents shared a representation that little would change as managed realignment was anchored to existing coastal management strategies which have traditionally sought to hold the line. When unexpected changes are encountered, as is likely with managed realignment, this can activate opposition (Weisner \& Schernewski, 2013). Third, this leads to difficulties with communication about the managed realignment concept, particularly where the outcome is often uncertain. The destination managers have provided interpretation materials on site and to local residents; however, the concept is complex and easily misunderstood. These issues are not easy to address and while adopting a managed realignment strategy can be a sound destination management decision on scientific grounds there are scenarios where it will present contentious issues for tourists. Recognising this at the outset will help manage tourist expectations at a time of change.

A limitation of this study is the focus on a specific destination with unique features and a tailored managed realignment strategy. Strategies, features of tourism interest and use values will vary in other destinations. Further research needs to address how social representations of managed realignment vary in different destination contexts, for instance, rural or urban and sites with high or low tourism numbers. Typically, social representations are context contingent and tourists with different use values are likely to draw on a representational field appropriate to the context. Further research is also needed to understand how different tourism stakeholder groups generate representations about coastal management strategies to assist stakeholder involvement in decision making.

\section{References}

Abel, N.R., Gorddard, R., Harman, B., Leitch, A., Langridge, J., Ryan, A. And Heyenga, S. (2011). Sea level rise, coastal development and planned retreat: analytical framework, governance principles and an Australian case study. Environmental Science \& Policy, 14(3), 279-288.

Bærenholdt, J.O., Haldrup, M., Larsen, J. and Urry, J. (2004). Performing Tourist Places. Aldershot: Ashgate.

Becken, S. (2013). A review of tourism and climate change as an evolving knowledge domain. Tourism Management Perspectives, 6, 53-62.

Becken, S. \& Hay, J.E. (2007). Tourism and Climate Change: Risk and Opportunities. Clevedon: Channel View Publications.

Bird, E.C.F. (1985). Coastline Changes: A Global Review. Geological Journal, 21(2), 215216.

Braun, O.L., Lohmann, M., Maksimovic, O., Meyer, M., Merkovic, A., Messerschmidt, E., Riedel, A. \& Turner, M. (1999). Potential impact of climate change effects on preferences for tourism destinations. A psychological pilot study. Climate Research, 11, 247-254.

Bryman, A., 2001. Social Research Methods. Oxford: Oxford University Press. 
Buzinde, C.N., Manuel-Navarrete, D., Eunice Eunjung, Y. \& Duarte, M. (2010). Tourists' Perceptions in a Climate of Change: Eroding Destinations. Annals of Tourism Research, 37(2), 333-354.

Buzinde, C.N., Manuel-Navarrete, D., Kerstetter, D. \& Redcliff, M. (2010). Representations and adaptation to climate change. Annals of Tourism Research, 37(3): 581-603.

Castro, P. \& Lima, M.L. (2001). Old and new ideas about the environment and science: an exploratory study. Environment and Behavior, 33(3), 400-423.

Coombes, E.G., Jones, A.P. (2010). Assessing the impact of climate change on visitor behaviour and habitat use at the coast: A UK case study. Global Environmental Change, 20, 303-313

Cowell, P.J., Bruce, G.T., Jones, R.A., Everts, C.H. \& Simanovic, D. (2006). Management of Uncertainty in Predicting Climate-Change Impacts on Beaches. Journal of Coastal Research, 22(1), 232-245.

Davidson, J. (1970). Outdoor Recreation Surveys: The design and use of questionnaires for site surveys. London: Countryside Commission.

de Rosa, A. S. (1994). From theory to metatheory in social representations: the lines of argument of a theoretical-methodological debate. Social Science Information, 33, 2, 273-304.

Doise, W., Clemence, A. \& Lorenzi-Cioldi, F. (1993). The Quantitative Analysis of Social Representations. London: Harvester Wheatsheaf.

Early, C. (2008). The slow advance of managed retreat. Environmental Data Services, 400, 36-39.

El-Raey, M., Dewindar, K. \& El-Hattab, M. (1999). Adaptation to the impacts of sea level rise in Egypt. Mitigation and Adaptation Strategies for Global Change, 4, 343-361.

Ergin, A., Williams, A.T. \& Michallef, A. (2006). Coastal Scenery: Appreciation and Evaluation. Journal of Coastal Research, 22(4), 958-964.

Esteves, L.S. (2014). Managed realignment: A viable long-term coastal management strategy? New York: Springer.

Evans, N., Campbell, D. \& Stonehouse, G. (2003). Strategic Management for Travel and Tourism. Burlington: Butterworth-Heinemann.

Fife-Schaw, C. (1993). Finding social representations in attribute checklists: how will we know when we have found one? In G.M. Breakwell \& D.V. Canter (Eds.), Empirical Approaches to Social Representations (pp. 248-271). Oxford: Clarendon Press.

Field, A. (2013). Discovering Statistics Using IBM SPSS Statistics. $4^{\text {th }}$ edition. London: Sage.

Finn, M., Elliott-White, M. \& Walton, M. (2000). Tourism and Leisure Research Methods: Data collection, analysis and interpretation. Harlow: Pearson Education.

Fredline, E. \& Faulkner, B. (2000). Host community reactions: a cluster analysis. Annals of Tourism Research, 27(3), 763-784.

Giles, D.C. (2002). Advanced Research Methods in Psychology. Hove: Routledge.

Greene, H. (2006). Taking Managed Realignment Forward as a Policy Option for Coastal Management in England and Wales. London: Chartered Institute of Water and Environmental Management.

Gurran, N., Norman, B. \& Hamin, E. (2013). Climate change adaptation in coastal Australia: An audit of planning practice. Ocean \& Coastal Management, 86, 100-109.

Guthrie, G.J.L. \& Ridgewell, J. (2011). Poole and Christchurch Bays Shoreline management Plan Review Sub-cell $5 f$ Hurst Spit to Durlston Head. Available at:

http://www.twobays.net/SMP2\%20Final/Main\%20Report/Section\%201.pdf (accessed $8^{\text {th }}$ January 2016).

Hadley, D. (2009). Land use and the coastal zone. Land Use Policy, 26S, S198-S203.

Hair, J.F., Black, W.C., Babin, B.J., Anderson, R.E. (2010). Multivariate Data Analysis: A Global Perspective. London: Pearson.

Hall, C.M. (2005). Place Competition in the Global Economy. In Hall, M.C. Tourism: Rethinking the Social Science of Mobility, Pearson: Harlow, 101-128.

Hamilton, J.M. (2007). Coastal landscape and the hedonic price of accommodation. Ecological Economics, 62(3-4), 594-602. 
Hammond, S. (1993). The descriptive analyses of shared representations. In G.M. Breakwell \& D.V. Canter (Eds.), Empirical Approaches to Social Representations (pp. 205-222). Oxford: Clarendon Press.

Hammond, S. (2000). Introduction to multivariate data analysis. In G.M. Breakwell, S. Hammond \& C. Fife-Schaw (Eds.), Research methods in psychology (pp. 372-396). London: Sage.

Hinkel, J., Nicholls, R., Tol, R.S.J., Wang, Z.B., Hamilton, J.M., Boot, G., Vafeidis, A.T., McFadden, L., ganopolski, A. \& Klein, R.J.T. (2013). A global analysis of erosion of sandy beaches and sea-level rise: An application of DIVA. Global and Planetary Change, 111, 150-158.

Houston, J.R. (2002). The Economic Value of Beaches- 2002 Update. Shore and Beach, 70(1), 9-12.

Houston, J.R. (2008). The Economic Value of Beaches- A 2008 Update. Shore and Beach, 76(3), 22-26.

Intergovernmental Panel on Climate Change (2014). Climate Change 2014: Impacts, Adaptation, and Vulnerability. Available at: http://www.ipcc.ch/report/ar5/wg2/ (accessed 6th Jan 2016).

Joffe, H. (2003). Risk: From perception to social representation. British Journal of Social

Psychology, 42, 55-73.

Jopp, R., DeLacy, T. \& Mair, J. (2010). Developing a framework for regional destination adaptation to climate change. Current Issues in Tourism, 13(6), 591-605.

Jopp, R., DeLacy, T., Mair, J. \& Fluker , M. (2013). Using a Regional Tourism Adaptation Framework to Determine Climate Change Adaptation Option for Victoria's Surf Coast. Asia Pacific Journal of Tourism Research, 18 (1-2), 144-164.

King, P., McGregor, A. \& Whittett, J. (2011). The economic costs of seal level rise to California beach communities. Fresno: California Department of Boating and Waterways. Available at: http://www.dbw.ca.gov/PDF/Reports/CalifSeaLevelRise.pdf (accessed 15 May 2014).

Lane, D., Mercer Clark, C., Forbes, D.L., Watson, P. (2013). The Gathering Storm: managing adaptation to environmental change in coastal communities and small islands. Sustainability Science, 8(3), 469-489.

Leiper, N. (2004). A Geography of Tourism: Places in Itineraries. In N. Leiper (Ed.), Tourism Management. 3rd ed (pp. 111-140). French Forest: Pearson Education.

Living with a Changing Coast Project (2014). The Residents' Guide to Coastal Change in Studland. Purbeck: Living with a Changing Coast Project.

Matasci, C., Kruse, S., Barawid N., Thalmann, P. (2014). Exploring barriers to climate change adaptation in the Swiss tourism sector. Mitigation and Adaptation Strategies for Global Change, 19,1239-1254

McDonald, E. (2012). Studland: Living with a changing coast- leaflet. Pubeck: Living with a Changing Coast Project.

McEvoy, D., Cavan, G., Handley, J., McMorrow, J. \& Lindley, S. (2008). Changes to Climate and Visitor Behaviour: Implications for Vulnerable Landscapes in the North West Region of England. Journal of Sustainable Tourism, 16(1), 101-121.

Met Office (2014). Winter storms, December 2013 to January 2014. Available at: http://www.metoffice.gov.uk/climate/uk/interesting/2013-decwind (accessed $1^{\text {st }}$ April 2016).

Michailidou, A.V., Vlachokostas, C., Moussiopoulos, N. (2016). Interactions between climate change and the tourism sector: Multiple-criteria decision analysis to assess mitigation and adaptation options in tourism areas. Tourism Management, 55, 1-12

Moreno, A. \& Becken, S. (2009). A climate change vulnerability assessment methodology for coastal tourism. Journal of Sustainable Tourism, 17(4), 473-488.

Moscovici, S. (1981). On social representations. In J. Forgas (Ed), Social Cognition (pp181209). London: Academic press. 
Moscovici, S. \& Hewstone, M. (1983) Social Representations and Social Explanations: From the 'Naïve' to the 'Amateur' Scientist. In M. Hewstone (ed), Attribution Theory (pp. 98-125). Oxford: Blackwell.

Myatt, L.B., Scrimshaw, M.D., Lester, J.N. (2003a). Public Perceptions and Attitudes Towards a Current Managed Realignment Scheme: Brancaster West Marsh, North Norfolk, U.K. Journal of Coastal Research, 19, 2, 278-286.

Myatt, L.B., Scrimshaw, M.D., Lester, J.N. (2003b). Public perceptions and attitudes towards a forthcoming managed realignment scheme: Freiston Shore, Lincolnshire, UK. Ocean \& Coastal Management, 46, 565-582.

Mycoo, M. (2014). Sustainable tourism, climate change and sea level rise adaptation policies in Barbados. Natural Resources Forum, 38, 47-57

National Trust (2008). Shifting Shores in the South West: Living with a changing coastline. Exeter: National Trust.

Phillips, M.R. \& Jones, A.L. (2006). Erosion and tourism infrastructure in the coastal zone: Problems, consequences and management. Tourism Management, 27, 517-524.

Purkhardt, S.C. \& Stockdale, J.E. (1993). Multidimensional scaling as a technique for the exploration and description of a social representation. In G.M. Breakwell \& D.V. Canter (Eds.), Empirical Approaches to Social Representations (pp. 272-297). Oxford: Clarendon.

Reddy, M.V. (2013). Global Tourism and Travel Industry: Performance During the DoubleDip Recession and Recommendations for Transition to a Green Economy. The World Financial Review, January $14^{\text {th }}, 26-31$.

Roca, E., Villares, M. (2012). Public perceptions of managed realignment strategies: The case study of the Ebro Delta in the Mediterranean basin. Ocean \& Coastal Management, 60, 38-47

Rowell, S. \& Richins, H. (2013). Tourism Industry responses to climate change in Hawai: An exploratory analysis of knowledge and responses. In M.V. Reddy \& K. Wilkes (Eds.), Tourism, Climate Change and Sustainability (pp.58-78). Oxford: Routledge.

Ryan, A., Gorddard, R., Abel, N., Leitch, A., Alexander, K., \& Wise, R. (2012). Perceptions of Sea-Level Rise and Managed Retreat: An Exploratory Survey. Clayton: CSIRO.

Sano, M., Gainza, J., Baumb, S., Choy, D.L., Neumann, S., Tomlinson, R. (2015). Coastal vulnerability and progress in climate change adaptation: An Australian case study. Regional Studies in Marine Science, 2, 113-123.

Scott, D., de Freitas, C.R., \& Matzarakis, A. (2006). Adaptation in the tourism and recreation sector. In K.L. Ebi, I. Burton, \& P. Hoeppe (Eds.), Biometeorology for adaptation to climate variability and change (pp. 171-194). Dordrecht: Springer.

Scott, D., Peeters, P. \& Gössling, S. (2010). Can tourism deliver its "aspirational" greenhouse gas emission reduction targets? Journal of Sustainable Tourism, 18(3), 393-408.

Scott, D., Simpson, M.C. \& Sim, R. (2012). The vulnerability of Caribbean coastal tourism to scenarios of climate change related sea level rise. Journal of Sustainable Tourism, 20(6), 883-898.

Scott, D., Hall, M.C. Gössling, S. (2016). A review of the IPCC Fifth Assessment and implications for tourism sector climate resilience and decarbonization. Journal of Sustainable Tourism, 24(1), 8-30.

Schleupner, C. (2008). Evaluation of coastal squeeze and its consequences for the Caribbean island Martinique. Ocean and Coastal Management, 51(5), 383-390.

Simpson, M., Gössling, S., Scott, D., Hall, C.M. \& Gladin, E. (2008). Climate change. Adaptation and mitigation in the tourism sector: Frameworks, tools and practices. Available at: http://www.unep.fr/shared/publications/pdf/DTIx1047xPAClimateChange.pdf (accessed 8th January 2016).

South West Research Company (2014). The Economic Impact of Dorset's Visitor Economy 2012: Dorset and Districts. Available at: http://www.visitdorset.com/dbimgs/Economic\%20Impact\%20of\%20Visitor\%20Economy\%20\%20Dorset\%20and\%20districts\%202012.pdf (accessed $8^{\text {th }}$ January 2016). 
Stanton, E.A. \& Ackerman, F. (2007). Florida and climate change: The costs of inaction. Medford, MA: Global Development and Environment Institute, Tufts University and Stockholm Environment Institute - US Center. Available at: http://www.ase.tufts.edu/gdae/Pubs/rp/Florida hr.pdf (accessed 8th January 2016).

Stemler, S. (2001). An overview of content analysis. Practical Assessment. Research \& Evaluation, 7(17). Available at: http://PAREonline.net/getvn.asp?v=7\&n=17 (accessed 14th Sept 2015).

Stoll-Kleemann, S., O'Riordan, T. \& Jaeger, C. C. (2001). The psychology of denial concerning climate mitigation measures: Evidence from Swiss focus groups. Global Environmental Change, 11 (2), 107-117.

Tabachnick, B.G. \& Fidell, L.S. (2001). Using multivariate statistics, Fourth Edition. London: Allyn and Bacon.

Tourism Alliance (2012). UK Tourism Statistics 2012. London: Tourism Alliance.

Uyarra, M.C., Cote, I.M., Gill, J.A., Tinch, R.R.T., Viner, D. \& Watkinson, A.R. (2005). Islandspecific preferences of tourists for environmental features: implications of climate change for tourism-dependent states. Environmental Conservation, 32(1), 11-19.

Voelklein, C. \& Howarth, C. (2005). A review of controversies about social representations theory: a British debate. Culture \& Psychology, 11, 431-454.

Weaver, D. (2011). Can sustainable tourism survive climate change? Journal of Sustainable Tourism, 19(1), 5-15.

Weber, R.P. (1990). Basic Content Analysis. London: Sage.

Weisner, E. \& Schernewski, G. (2013). Adaptation to climate change: A combined coastal protection and re-alignment measure in a southern Baltic tourism region. Journal of Coastal Research, Special Issue No. 65, 1963-1968.

Wong, E., Jiang, M., Klint, L., DeLacey, T., Harrison, D. \& Dominey-Hows, D. (2013). Policy Environment for the Tourism Sector's Adaptation to Climate Change in the South Pacific - The Case of Samoa. Asia Pacific Journal of Tourism Research, 18(1-2), 5271. 